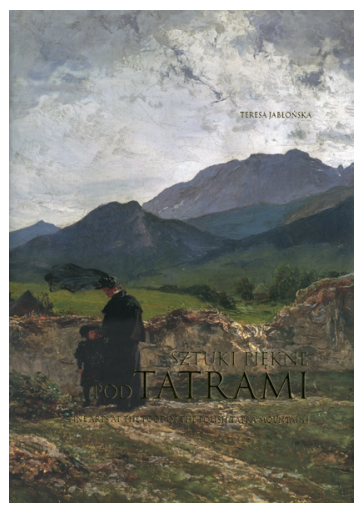

\title{
Sztuki piękne pod Tatrami
}

DOI: $10.19195 / 2084-4107.10 .21$

[rec.:] Teresa Jabłońska, Sztuki piękne pod Tatrami. Fine arts at the foot of the Polish Tatra mountains, wyd. Tatrzański Park Narodowy, Muzeum Tatrzańskie w Zakopanem, Zakopane 2015, ss. 480.

Fine arts in the Tatras

Słowa-klucze: Tatry, sztuka, malarstwo, rzemiosło artystyczne

Keywords: Tatras, art, painting, handicrafts

W roku 1957 w pierwszym numerze czasopisma „Literatura Ludowa” wybitny historyk literatury polskiej profesor Julian Krzyżanowski napisał:

Gdyby zapytać, jakie strony Polski w obrębie ostatnich stu lat wiązały się szczególnie trwale z literaturą, odpowiedź brzmiałaby niewątpliwie: Tatry i Podhale. Na dowód dość byłoby wymienić dziesiątek nazwisk tego rzędu, co Asnyk, Witkiewicz, Sienkiewicz, Kasprowicz, Tetmajer, Żeromski, Orkan, Sieroszewski, Miciński, wskazujących, że jak w czasach Słowackiego krainą najchętniej nawiedzaną przez muzę romantyczną były „Ukrainy błękitne Pola”, tak w sto lat później zainteresowania literackie skupiły się wokół Podhala ${ }^{1}$.

Krzyżanowski uwagę swą skupił na bodaj szczególnie bliskich jego zainteresowań historycznoliterackich czasach schyłku XIX i początków XX w. Godzi się jednak pamiętać, że w ciągu XIX i XX w. Tatry i Podhale zajęły autentycznie

1 J. Krzyżanowski, Folklor Podhala w literaturze, „Literatura Ludowa” 1957, nr 1, s. 5. 
ważne miejsce nie tylko w literaturze, ale i w sztukach pięknych, Zakopane zaś odegrało istotną rolę w dziejach życia artystycznego. Poszerzając więc chronologiczny i merytoryczny zakres takiej refleksji, do nazwisk wymienionych przez Krzyżanowskiego dorzucić można jeszcze spory wykaz nazwisk wybitnych twórców związanych z Tatrami, reprezentujących inne dziedziny niż literatura, uwzględniając sztuki plastyczne, muzykę, fotografikę i film. Wówczas w pełniejszej skali ukaże się inspiratorska rola Tatr w twórczości artystycznej, wskazująca na ich szczególne miejsce w kulturze polskiej. O sprawach tego dotyczących pisano sporo i w różnych aspektach ${ }^{2}$. Pomijając tu literacki aspekt tego zagadnienia, mówiąc zaś o malarstwie, warto dla jasności wywodu przypomnieć rzecz tak oczywistą, jak fakt, iż tematyka tatrzańska i podhalańska zajęła ważne miejsce w twórczości tak wybitnych lub choćby tylko wyraźnie wpisanych w dzieje sztuki polskiej malarzy, jak na przykład Jan Nepomucen Głowacki, Aleksander Kotsis, Władysław Ślewiński, Olga Boznańska, Wojciech Gerson, Leon Wyczółkowski, Walery Eliasz, Stanisław Witkiewicz i Stanisław Ignacy Witkiewicz... To przypomnienie jest wprawdzie truizmem, ale dopowiedzieć do niego trzeba, że o ich dokonaniach twórczych pisano zazwyczaj — trochę w analogii do badań literaturoznawczych - w perspektywie tematologicznej, ale w oderwaniu jednak od szerszego kontekstu całości zjawisk kulturowych, dotyczących tego kręgu tematycznego. Analizowano więc, kto, co i jak malował, w ten sposób mniej lub bardziej wyraźnie opisując historię malarstwa o tematyce tatrzańskiej i podhalańskiej, widzianej z uwzględnieniem przemian stylu, jakie zaszły w sztuce XIX i XX w. Stąd nie przypadkiem wydawnictwa dotyczące tej problematyki miały przede wszystkim charakter albumowy' wartościowych zaś z naukowego punktu widzenia prac pojawiło się $\mathrm{w}$ gruncie rzeczy niewiele ${ }^{3}$. Na tym tle księga Teresy Jabłońskiej Sztuki piękne pod Tatrami jawi się jako dokonanie nowatorskie o niezaprzeczalnie dużej wartości i wyrazistej tożsamości metodologicznej. Mieli tego świadomość wydawcy dzieła, w znacznym jednak uproszczeniu, pisząc: „Uważamy ten album za niezwykle ważny. Dlaczego? Otóż jest to pierwsza publikacja kompleksowo ukazująca artystyczno-intelektualny fenomen, jakim było środo-

2 Rola Zakopanego w historii życia literackiego czeka na solidne opracowanie, została bowiem dotychczas zaledwie naszkicowana w kilku fragmentach i kilku tylko aspektach, związanych m.in. z Witkacym i występami futurystów. O innych aspektach życia artystycznego zob. np. K. Estreicher, Środowisko artystyczne Zakopanego w okresie Młodej Polski (1900-1914), [w:] Sztuka około 1900, Kraków 1967, s. 129-140; J. Młodziejowski, Góry polskie w polskiej muzyce, [w:] Sympozjum „, Góry w kulturze polskiej”, Kraków 9-10 listopada 1974 r., Kraków 1975, s. 95; M. Pinkwart, Tatry w świadomości mieszkańców Zakopanego i ich gości. Prasa zakopiańska 1891-1939, Zakopane 2002; L. Długołęcka, M. Pinkwart, Muzyka i Tatry, Warszawa-Kraków 1992, T. Ochotnicka, Teatr w Zakopanem w latach 1870-1939, „Rocznik Podhalański” 3, 1985, s. 187-243.

3 O Tatrach w malarstwie zob. J. Woźniakowski, Tatry i malarze, [w:] M. Jagiełło, J. Woźniakowski, Tatry w poezji i sztuce polskiej, Kraków 1975; J. Banach, Tatry malownicze. Polski pejzaż górski 1800-1950, [w:] Sympozjum „, Góry w kulturze polskiej”.... G. Niewiadomy, Krajobraz z góralem. Tatry i Podhalanie w sztuce polskiej, Gdańsk 1995; A. Król, Wiatr halny. „Krajowidoki”, $i$ wrażenia: Tatry w malarstwie polskim XIX i XX wieku, Szczecin 2006.

Góry — Literatura — Kultura 10, 2016

(C) for this edition by CNS 
wisko twórcze pod Tatrami"4. Istotnie w tym znakomitym opus magnum Teresy Jabłońskiej Sztuki piękne pod Tatrami rzecz potraktowana została w sposób nowatorski - podmiotowo, co oznacza, że w roli istotnego czynnika porządkującego narrację historyczną przywołany został genius loci jako suwerennie ważny czynnik sprawczy, inspirujący twórczość artystyczną, słowem - jako zespół faktów suwerennych, być może komplementarny w stosunku do innych aspektów zagadnienia. W niczym nie umniejsza to roli przemian zachodzących $\mathrm{w}$ świadomości estetycznej i w kierunkach artystycznych, które patronowały poszczególnym ujęciom szerokiego kręgu zjawisk ogarniętych przez Teresę Jabłońską. Jako historyk sztuki legitymuje się ona wieloma cennymi pracami dotyczącymi zarówno malarstwa polskiego, jak i rozległej problematyki stylu zakopiańskiego: swoje wybitne kompetencje w zakresie tego kręgu zagadnień zademonstrowała ona w efektownej monografii - albumie Styl zakopiański Stanisława Witkiewicza (2008), natomiast Muzeum Tatrzańskie zawdzięcza Teresie Jabłońskiej bardzo wiele. Dzięki niej w zakopiańskiej Kolibie znalazła się spora kolekcja prac Stanisława Ignacego Witkiewicza, dzięki jej poczynaniom — wyremontowana została zakopiańska Oksza i powstała w niej ciekawa ekspozycja sztuki XX w.

Sama zaś autorka tej ogromnej księgi we wstępnych uwagach, mających charakter metodologiczny, napisała (chyba zbyt ostrożnie):

Sztuce „z kręgu Tatr” poświęcono wiele opracowań naukowych oraz publikacji popularnych i wystaw, omawiana była w towarzyszących im katalogach i wydawnictwach monograficznych, prezentowana $\mathrm{w}$ albumach, filmach etc. Ustalenia autorów tych prac były często pionierskie i niniejszy album w znacznej mierze na nich się opiera. Różni się jednak od dotychczasowych wydawnictw albumowych, zwykle monograficznych i poświęconych najczęściej krajobrazowi tatrzańskiemu, szerszą tematyką i rozmaitością dyscyplin artystycznych. Obejmuje bowiem malarstwo, rysunek, grafikę i fotografię (nie tylko krajobrazową), rzeźbę oraz sztukę użytkową z okresu od początku XIX wieku do 1939 roku. Taki zakres rzeczowy i czasowy pozwala prześledzić rozwój „nurtu tatrzańskiego" od momentu jego pojawienia się w sztuce polskiej i zarazem w najważniejszym dla niego — w znacznej mierze odkrywczym — okresie. Nie jest to pełny obraz „tatrzańskiej spuścizny artystycznej”, lecz rodzaj antologii, wybór mający na celu pokazanie różnorodności i bogactwa sztuki inspirowanej Tatrami i sztuką góralską ${ }^{5}$.

Dzieło Teresy Jabłońskiej na pewno nie jest ,antologią”, nie jest też w ścisłym słowa znaczeniu albumem, choć jest to książka bogato ilustrowana i zamieszczono w niej liczne reprodukcje bardzo wielu dzieł sztuki, i śmiało rzec można, że chyba ani jedna $\mathrm{z}$ wydanych do tej pory książek o Tatrach w malarstwie pod

4 T. Jabłońska, Sztuki piękne pod Tatrami, Wyd. Tatrzański Park Narodowy i Muzeum Tatrzańskie, Zakopane 2015, s. 5.

5 Ibidem, s. 11-13. 
względem ilościowym w tym zakresie absolutnie nie może się równać. Sztuki piękne pod Tatrami są bowiem precyzyjną monografią rozległego kompleksu zjawisk z zakresu sztuk pięknych i życia artystycznego, w niej zaś odautorski tekst jest w pełni suwerenny, aczkolwiek ściśle koresponduje ze znakomicie dobranymi ilustracjami.

Istotnym aspektem wartości dzieła jest wyraźna korespondencja między narracją słowną a narracją ikoniczną, którą tworzą ilustracje. Niewątpliwą przy tym zaletą obranej formuły edytorskiej jest to, że zespół miniatur towarzyszących tekstowi słownemu niejako przygotowuje czytelniczy odbiór - ogląd albumowo potraktowanych reprodukcji tych samych dzieł. ${ }^{6}$ W ten sposób książka, w której wzajemnie się dopełniają tekst monografii i album, nie tracąc naukowej ścisłości, zachowuje charakter popularny. Nie zmienia to jednak faktu, że choć autorka we wstępie anonsuje swe dzieło jako publikację adresowaną do szerokiego kręgu „miłośników sztuki, Tatr i Zakopanego oraz amatorów wszelkich fenomenów i demonizmów związanych z tymi ciekawymi i przepięknymi miejscami"7, to Sztuki piękne pod Tatrami mają liczne walory istotnego dokonania naukowego. Teresa Jabłońska nie zamęcza swego czytelnika naukową terminologią, która w książce pojawia się na miarę quantum satis, nie epatuje ani przesadną szczegółowością faktografii, ani cytowaniem anegdotek, których, szczególnie w odniesieniu do Młodej Polski tatrzańskiej i Witkacego, można opowiedzieć tysiąc — jest zaś rozsądnie rzeczowa, swobodnie przechodzi od analizy szczegółów do wynikających z nich sądów uogólniających.

Mówiąc o metodologicznych aspektach dzieła, trzeba zwrócić uwagę na pewne szczególnie istotne momenty. Pierwszym z nich jest fakt, że Teresa Jabłońska swymi rozważaniami objęła wszystkie rodzaje sztuk plastycznych, wskutek czego jej książka jest rzeczywiście dziełem o sztukach pięknych i daje zrównoważony obraz znaczenia różnych form ekspresji artystycznej, szeroko rozumianej tematyki tatrzańskiej i podhalańskiej.

Aspekt drugi wiąże się z dobrym wykorzystaniem rozległego stanu badań, a także ze skorzystaniem z inspiracji, jaką dać mogły fundamentalne prace Karola Estreichera (Środowisko artystyczne Zakopanego w okresie Młodej Polski, 1967) i Jacka Woźniakowskiego (Dobrańsze niż gdzie indziej towarzystwo. Życie artystyczne w Zakopanem do roku 1939, 1991). Wskutek tego monografia Jabłońskiej przemiany stylowe $\mathrm{w}$ artystycznych realizacjach tematyki tatrzańskiej i podhalańskiej celnie łączy z dziejami środowiska artystycznego gromadzącego się pod Tatrami i uksztaltowaniem się ośrodka artystycznego życia w Zakopanem.

Doceniając rolę górskiej turystyki i taternictwa (to novum w pisaniu o sztuce $)^{8} \mathrm{w}$ tym procesie i różne aspekty jej instytucjonalizacji, autorka stworzyła nowy zupełnie obraz tego życia, eksponując jego funkcjonalność. Niewątpliwe

${ }^{6}$ Nie znaczy to jednak wcale, by kształt edytorski książki zastosowany przez wydawcę uznać za szczególnie udatny. Będzie o tym mowa niżej.

7 Ibidem, s. 13.

8 Zob. szczególnie T. Jabłońska, op. cit., s. 81. 
znaczenie w omówieniu zjawisk jakie zaszły na przełomie XIX i XX w. (aż po rok 1914), miało tu zastosowanie do życia artystycznego w Zakopanem pojęcia „Młodej Polski tatrzańskiej”. Stworzył je Tadeusz Boy-Żeleński, stosowane zaś dotąd było głównie w odniesieniu do zjawisk zachodzących w literaturze - a przecież jednak jego użycie w kontekście życia artystycznego w Zakopanem jest słuszne i jawi się jako w pełni uzasadnione. Trochę jednak szkoda, że autorka pominęła niemal całkowicie nie tylko parantele zjawisk zachodzących w sztuce z literaturą, lecz także najbardziej spektakularne momenty życia muzycznego w Zakopanem, a przecież życie literackie i muzyczne Zakopanego stanowiły istotny element podtatrzańskiego życia artystycznego. Wspomniany kontekst literacki w paru wypadkach był szczególnie pożądany, by wspomnieć tylko o relacji Norwida z pracownią Jana Nepomucena Głowackiego - autorka Norwida zacytowała, ale z jego uwag wniosków nie wyprowadziła, nie zauważając, co pisał o tym Kazimierz Wyka $^{9}$, a co wiązało się z szerszym problemami kondycji malarstwa polskiego w pierwszej połowie XIX w. Tematyka tatrzańska w sztuce nie rozwijała się w zamkniętym procesie autonomicznym, literatura zaś w twórczym poznaniu Tatr odegrała istotną rolę i można było o tym dwa słowa powiedzieć, acz wątku tego specjalnie rozwijać nie było trzeba.

Uwaga ta nie zmienia faktu, że książka Teresy Jabłońskiej jest wybitnym dokonaniem zasłużonej muzealniczki, przez lat wiele pełniącej funkcję dyrektora Muzeum Tatrzańskiego w Zakopanem i w jednej osobie autorki cennych dzieł z zakresu historii sztuki, świetnej znawczyni problematyki stylu zakopiańskiego. Trudno tu jednak uniknąć refleksji sceptycznej: Sztuki piękne pod Tatrami otrzymały wprawdzie Grand Prix 4. Konkursu na Książkę Górską Roku im. Wawrzyńca Żuławskiego za rok 2016 i doczekały się pochlebnych opinii internautów, ale z punktu widzenia sztuki edytorskiej nie można tej ogromnej, ciężkiej, czterokilogramowej księgi ${ }^{10}$ dużego formatu ocenić pozytywnie: jej techniczna strona uderza błędami dowodzącymi braku profesjonalizmu wydawcy, w następstwie czego korzystanie z tej księgi jest ogromnie niewygodne, praktycznie ograniczone do minimum - jest po prostu trudne i wręcz uciążliwe. W dodatku kilkakrotne przekartkowanie tej książki sprawia, że zaczyna się ona „rozłazić”. Na szczęście tekst napisany przez Teresę Jabłońską ma autentycznie dużą wartość, acz szkoda, że korzysta się z niego kosztem niepotrzebnie dużych trudności...

Jacek Kolbuszewski

9 K. Wyka, Norwid w Krakowie, [w:] Cyprian Norwid. Studia, artykuły, recenzje, Kraków 1989, s. 332. (Pierwodruk: „Pamiętnik Literacki” 1967, z. 2).

10 Na kpinę zakrawa fakt, iż pierwszą limitowaną serię edycji tej księgi wydawcy sprzedawali, reklamując, że dodają do niej... specjalne pudełko! 